\title{
Foreign Firms Listing In The U.S.: Signaling Commitment To The U.S. Market
}

Timothy Kruse, Ph.D. Xavier University, USA

Michael Webb, Ph.D., Xavier University, USA

Shelly Webb, Ph.D., Xavier University, USA

\begin{abstract}
We hypothesize that the cost associated with the listing decision - including the greater scrutiny of U.S. investors - signals the depth of the firm's commitment to the U.S. market to potential business partners and employees, providing a form of bonding that is directed within the U.S. Firms can credibly signal their commitment to the U.S. market by listing on more prestigious exchanges that bring greater investor scrutiny and, especially, by listing directly rather than using ADRs. We find strong evidence that firms with greater sales in the U.S. and those with a greater proportion of their sales to the U.S. are more likely to list directly in the U.S; firms with greater assets in the U.S. are more likely to list directly. With the greater scrutiny for companies that list on the NYSE, we expect the hypotheses to hold for the decision to list there versus elsewhere. With the exception of sales level in the U.S., we find evidence for the relationships described above hold for the decisions to list on the NYSE.
\end{abstract}

Keywords: International Finance Cross-Listing; Listing; American Depositary Receipts

\section{INTRODUCTION}

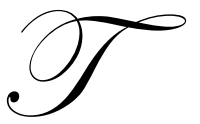

he pace of globalization of goods markets in the past 40 years has been accompanied by an even greater integration of financial markets. The U.S. financial market has been particularly attractive to both investors and companies seeking sources of funds. According to a 2011 report from BNY Mellon, over 1,500 depository receipt programs have been initiated worldwide annually from 2002 through 2010, with about 500 or more of them each year in the U.S. U.S.-listed programs accounted for almost $86 \%$ of all depository trading value worldwide, with the New York Stock Exchange (NYSE) and NASDAQ the largest markets for trading in the U.S.

And yet, it is costly for a company to list on a U.S. exchange. The Securities and Exchange Commission (SEC) requires that many firms listing on one of the U.S. exchanges reconcile their net income and stockholders' equity using U.S. Generally Accepted Accounting Principles (GAAP). As Choi and Levich (1990) show, the task of reconciliation is costly for foreign firms choosing to list on U.S. financial markets, so foreign firms choosing to list on a U.S. market must have gains to offset the costs (Solnik, 1988). And researchers find a net gain for foreign firms that list in the U.S. Sundaram and Logue (1996) find a 10\% increase in value for companies that list on one of the two major exchanges in the U.S., while Doidge, Karolyi and Stulz (2004) find that companies cross-listing in the U.S. enjoy a $16.7 \%$ premium, rising to $37 \%$ for those on major U.S. exchanges.

There exists a considerable literature regarding the decision of foreign firms to list in the U.S.; see Gagnon and Karolyi (2010). Generally, the gains from listing in the U.S. fall into three categories: gaining access to new investors in a deeper capital market, signaling potential investors by submitting to the SEC and the scrutiny of U.S. analysts, and reducing the barriers to doing business in the U.S. We focus on the desire to reduce barriers to doing business in the U.S., and how this affects the decision by a foreign firm to list directly or with ADRs, as well as whether to list on a higher profile exchange. We hypothesize that firms with greater sales in the U.S., (a greater market relationship), greater proportion of sales in the U.S. (a greater market focus), and greater assets in the U.S. (and so with public relations concerns), are more likely to list directly and on higher profile exchanges. They do this 
in order to signal their commitment to the U.S. market to potential U.S. customers, suppliers, and employees. We analyze a sample of 1207 companies that cross-listed in the U.S. in 2004 and find strong evidence to support all three hypotheses in regard to listing direct versus through ADRs and two out of three in regard to listing in higher profile exchanges.

\section{LITERATURE REVIEW: THE FOREIGN FIRM'S DECISION ON WHETHER TO LIST IN THE U.S.}

There are three potential sources of gain for companies listing in the U.S. First, the most straightforward gain is from increased access to new investors and a deeper, more efficient financial market. Saudagaran (1987) finds that listing in a foreign exchange market is more likely for a firm that is larger in comparison to its domestic market - and so likely to have exhausted domestic sources of funds - and for a firm that is more dependent on foreign sales. Karolyi (1996) also finds evidence that foreign listing is designed to reduce a firm's risk associated with raising capital and reduce its cost of equity capital. Finally, Pagano, Röell, and Zechner (2002) find that a foreign firm listing in the U.S. is more likely to be comparatively large, recently privatized, and in the high technology sector - and so is more likely to be seeking an additional source of funding.

Second, foreign firms might take advantage of the benefits of SEC oversight, monitoring by U.S. analysts, and the relative strictness of U.S. laws and regulations. In fact, Biddle and Saudagaran (1991), Saudagaran and Biddle (1992, 1995), and Cheung and Lee (1995) provide evidence that increasing disclosure levels in a foreign market reduces the likelihood that a firm will list on a foreign stock exchange. On the other hand, U.S. laws and institutions can protect minority shareholders from overseas markets with comparatively poor oversight of corporate governance; listing in the U.S. subjects the firm to SEC and investor oversight in U.S. markets and so provides a bonding mechanism for the firm and increases its attractiveness to the pool of potential investors in its home country. Doidge (2004) finds that non-U.S. firms listing in the U.S. possess a $43 \%$ lower voting premium than comparable non-U.S. firms that do not list. Doidge, Karolyi and Stulz (2004) find that foreign firms listing on a major U.S. exchange have Tobin's q ratios 37\% higher than for similar firms not listed on the major U.S. exchange, and that expected sales growth is valued more highly for firms listed in the U.S., especially for those from countries with poorer investor rights. In both cases, they conclude that the greater transparency provided by firms listing in the U.S. provides a strong signal to potential investors that controlling interests plan to maximize the firm's value. Salva (2003) finds a similarly positive effect for foreign firms listing on the London exchange. Consistent with their previous finding, Doidge, Karolyi and Stulz (2009) find that the premium for listing in the U.S. is unaffected by Sarbanes-Oxley.

While GAAP reconciliation and SEC oversight are important, there is evidence that the informal oversight of investors in the U.S. markets plays a key role for companies. Lang, Lins, and Miller, (2003) find that listing in the U.S. increases analyst coverage of foreign firms, and that increasing analyst coverage increases firm valuation. Siegel (2005) finds that SEC actions are not relevant for Mexican firms, while the evaluations of analysts do have an impact. The lack of official SEC action toward firms that violate its rules may not imply SEC inaction behind the scenes, though it does mean that the scrutiny of the SEC or investors in the U.S. market is informal. From Lang, Lins, and Miller, (2003) and Siegel (2005), we can conclude that the greater benefit of listing in the U.S. comes not from legal bonding, but from reputational bonding - the informal bonding that occurs from the scrutiny of investors in the U.S market.

Finally, firms may list in an overseas market in order to reduce the barriers to doing business there. Saudagaran (1987) hypothesizes that "coverage by local media provides 'free' advertising that is especially beneficial for producers of industrial and consumer products that would spend large sums to garner such visibility," and he finds that firms with greater foreign sales are more likely to list abroad. Saudagaran and Biddle (1995) find that a multinational is more likely to list in countries where it has greater sales; Mittoo (1992) finds similar results for Canadian firms.

While it is clear that foreign firms gain from listing in the U.S. market, the determinants of how foreign companies choose the method of listing in the U.S. is less studied. Firms may list directly or employ ADRs, which represent underlying common shares of the company in its home market and are denominated in U.S. dollars. ADRs may be sponsored, in which case a firm submits its financial reports at least annually and provides the reports in 
English. Types 2 and 3 sponsorships allow ADRs to be listed on one of the major exchanges in the U.S., but require GAAP reconciliation and more detailed and frequent reporting to the SEC.

The type of listing a firm selects is unlikely to affect its access to the deep pockets of the U.S. financial market. We do expect that investing in a higher profile listing - which has higher fixed costs - credibly signals the importance that a foreign firm places on the U.S. market, and therefore affects its business relationships in the U.S. A firm can provide a credible commitment to the U.S. market by listing directly and by listing on the American or New York stock exchanges (AMEX or NYSE) rather than over the counter (OTC) on the NASDAQ. This is the topic we explore next.

\section{HYPOTHESES: THE FOREIGN FIRM'S DECISION ON HOW AND WHERE TO LIST IN THE U.S.}

The general question we address is how firms decide whether to undertake the additional cost of listing directly in the U.S. versus listing via ADRs. While the decision-making regarding how to list in a foreign market is related to the decision-making in regard to whether to list, it is also likely to differ in important ways. The primary gain from listing in the U.S. comes from the signal conveyed when a firm undertakes the sunk cost of listing directly and exposes itself to greater scrutiny by U.S. investors. The credible signal associated with listing that is more direct or that takes place on a more prestigious exchange will strengthen a firm's relationships with current and potential U.S. customers, suppliers, and employees. Customers and suppliers often need to make specific investments in terms of their supply chain or manufacturing. They will be more likely to make these investments, or increase them, when a foreign firm has undertaken the sunk cost of listing directly in the U.S. financial market. Employees of companies that have incurred the sunk cost of directly listing in the U.S. will be more willing to invest in learning and other activities to enhance company-specific productivity. Higher quality employees who have alternative employment opportunities will be more likely to select companies that have signaled a longer term commitment to the U.S. market; those lured from other firms must be willing to undertake the likely monetary costs and certain psychological costs of moving to a new firm and perhaps living in a new location. Listing in the U.S. provides bonding for the foreign firm, but bonding is not only a signal to potential shareholders in the firm's home market, but also to potential investors across the globe and potential business partners in the U.S.

Our first hypothesis is that increasing sales in the U.S. confers a market relationship gain from listing directly in the U.S., and we predict that firms with greater U.S. sales will be more likely to list directly in the U.S. Secondly, we expect that firms with sales focused in the U.S. are more likely to value their relationships there - a market focus gain. For firms of similar size, we predict that firms with a greater proportion of their sales in the U.S. are more likely to list directly. The bonding gain for home shareholders does not yield either of the predictions. Consequently, we see them as complementing the findings of Doidge (2004) and Doidge, Karolyi, and Stulz (2004) that listing in the U.S. provides protection for minority investors.

Third, when a company increases its assets in the U.S., whether due to a construction of new operational facilities from the ground up, local acquisition, or a combination of the two, political and employee goodwill are especially important. Laws and political relationships - local, state, and national - become increasingly important. We hypothesize that for firms with greater assets in the U.S. there is a greater public relations gain from listing directly and signaling a long-term commitment to the U.S. market; firms with greater assets in the U.S. are more likely to list in the U.S. directly. Fourth, to the extent that other firms from its home country have invested in the U.S. - ensuring influence from like-minded firms on laws and their implementation in the U.S. - the gains from directly listing are reduced. The free rider effect leads us to predict that a firm from a country with a large stock of foreign direct investment is less likely to directly list in the U.S.

Because we are looking at U.S. equity markets and because they are large and provide access to funds that may not be available in a company's home market, we expect that the company's revenues and asset size relative to GDP of its home country will impact its listing decision in the U.S. As noted earlier, previous studies have found that companies are more likely to list abroad if their assets are large relative to their home country GDP. We expect that companies that are large relative to their home market, in term of sales and total assets, are more likely to enter the U.S. equity market for primarily financial reasons and so are more likely to employ ADRs. The financial focus effect would predict that, all else equal, firms with larger sales and assets relative to the size of their home market are less likely to list directly in the U.S. 
Given the requirements to be listed on the NYSE and greater scrutiny for companies that list there, the relationships and hypothesized effects provided above should hold for the decision to list on the NYSE versus listing elsewhere.

\section{ANALYSIS}

Our initial sample consists of 1648 foreign firms in the Research Insight database for the calendar year 2004. We obtain financial data and information on the type and location of U.S. listing, and hand collect data not available in Research Insight from annual reports. After deleting inactive firms and firms for which there is no data, the final sample consists of 1207 firms from 53 countries. The appendix contains a list of home countries and the number and percentage of firms using direct listing and ADRs. We obtain home country data on GNP and Foreign Direct Investment (FDI) from the IMF's International Financial Statistics.

Table 1 provides a break-down of our sample firms by regions and country groupings. A little more than half come from the British Commonwealth countries and as shown in Appendix A, about half that amount comes from Canada. While firms from the European Union, Latin America, and Asia rely heavily on ADRs, those from the British Commonwealth tend to list directly.

Table 1

Listing and ADR use by regions and country groupings

\begin{tabular}{lccc}
\hline \multicolumn{1}{c}{ Regions } & $\begin{array}{c}\text { Total Number } \\
\text { Listing in U.S. }\end{array}$ & \multicolumn{2}{c}{ Firms Using ADRs } \\
& 306 & 274 & Number \\
\hline European Union & 616 & 183 & 90 \\
British Commonwealth & 133 & 123 & 30 \\
Latin America & 131 & 120 & 92 \\
Asia & &
\end{tabular}

Table 2 reports selected financial and macroeconomic data for companies choosing to list in the U.S. We Winsorize the data at the one and 99 percentiles to reduce the effect of outliers. Even so, the differences in means and medians suggest that there is a wide variance in the sizes of firms that list in the U.S., with average company sales at close to $\$ 8$ billion and median at $\$ 2.5$ billion, with mean and median sales to the U.S. coming in at fairly similar proportion, at almost $33 \%$ for mean and $30 \%$ for median sales to the U.S. Both company assets and proportion of assets in the U.S. are dispersed, with average company assets at approximately $\$ 35$ billion and the median at $\$ 1.4$ billion; the proportion of assets in the U.S. is using mean numbers at $22 \%$, and for median numbers at almost $7 \%$.

Table 2

Selected firm level data (Winsorized to reduce the impact of outliers)

\begin{tabular}{lccc}
\hline & $\mathbf{N}$ & Mean & Median \\
\hline Company sales (\$ billions) & 1077 & 8.194 & 0.931 \\
Company sales to GNP & 916 & 0.010 & 0.001 \\
Company U.S. sales (\$billions) & 724 & 2.546 & 0.201 \\
Proportion of sales in U.S. & 698 & 0.336 & 0.300 \\
Company total assets (\$ billions) & 1078 & 35.468 & 1.454 \\
Company total assets to GNP & 916 & 0.047 & 0.002 \\
Company assets in the U.S. (\$ billions) & 635 & 8.794 & 0.102 \\
\hline
\end{tabular}

We present the results of logistic regressions of the listing decision in Tables 3 and 4. Panels A and B in Table 3 provide estimates of the determinants of a firm's decision to list directly or via an ADR. Though Panel A addresses direct listing versus listing with Types 2 or 3 ADRs and Panel B includes Type 1 ADRs with the others, the results are virtually identical. We provide four models so we can provide results with and without the regional dummy variables, as well as with and without company assets divided by the firm's home county GNP. 
We find evidence confirming our hypothesis that increasing sales in the U.S. confers a market relationship gain from listing directly in the U.S., increasing the likelihood of a firm doing so. The level of company sales in the U.S. is positive and highly significant for all four models. We also find strong evidence, with positive and significant coefficients in all four models, confirming that firms with a greater proportion of their sales in U.S. are more likely to list, consistent the presence of a market focus gain. It's important to note that this effect is not predicted by bonding for home shareholders, but is explained by the relative importance of the signal that occurs within the U.S. It is interesting to note that the two variables have significant impacts when accounting for the other and the proportion of company sales in home country GNP.

The coefficient for company total assets in the U.S. is positive and significant in all four models, while total FDI from a firm's home country is significantly negative in all four cases. This result provides strong support for the public relations gain from listing directly, as well as the free rider effect that reduces the likelihood that a firm from a country with a large stock of foreign direct investment will directly invest.

Because we are looking at U.S. equity markets and because they are large and provide access to funds that may not be available in a foreign company's home market, we expect that the company's revenues and asset size relative to GNP of its home country will impact its listing decision in the U.S. Interestingly, we find that while sales relative to home country GNP is consistently significant and has the expected effect - they are less likely to list directly - we find that assets relative to GNP consistently shows no significant impact on the firm listing decisions.

Table 3

Logit results: Listing Directly versus Listing with ADRs (with p-values)

Panel A: Listing Directly Versus Listing with ADRs Types 2 and 3

Dependent variable equals one if common stock issued, zero if ADR

\begin{tabular}{|c|c|c|c|c|}
\hline & Model 1 & Model 2 & Model 3 & Model 4 \\
\hline Intercept & $\begin{array}{l}2.03 * * * \\
(0.0001) \\
\end{array}$ & $\begin{array}{l}1.99 * * * \\
(0.0001)\end{array}$ & $\begin{array}{c}0.77 * * \\
(0.0236)\end{array}$ & $\begin{array}{c}0.74 * * \\
(0.0276) \\
\end{array}$ \\
\hline Company Sales/GNP & $\begin{array}{c}-212.5 * * * \\
(0.0001)\end{array}$ & $\begin{array}{c}-195.7 * * * \\
(0.0001) \\
\end{array}$ & $\begin{array}{c}-162.1 * * * \\
(0.0001) \\
\end{array}$ & $\begin{array}{c}-151.0 * * * \\
(0.0001)\end{array}$ \\
\hline Company Total Assets /GNP & $\begin{array}{c}3.41 \\
(0.1679) \\
\end{array}$ & & $\begin{array}{c}2.05 \\
(0.4316) \\
\end{array}$ & \\
\hline $\begin{array}{l}\text { Company Sales in US } \\
\text { ( } \$ \text { billions })\end{array}$ & $\begin{array}{l}0.30 * * * \\
(0.0001) \\
\end{array}$ & $\begin{array}{l}0.27 * * * \\
(0.0001) \\
\end{array}$ & $\begin{array}{l}0.23 * * * \\
(0.0001) \\
\end{array}$ & $\begin{array}{l}0.22 * * * \\
(0.0001) \\
\end{array}$ \\
\hline Proportion of sales in US & $\begin{array}{c}1.40 * * \\
(0.0122)\end{array}$ & $\begin{array}{l}1.44^{* * * *} \\
(0.0100)\end{array}$ & $\begin{array}{c}1.45^{* *} \\
(0.0280)\end{array}$ & $\begin{array}{l}1.49 * * \\
(0.0243)\end{array}$ \\
\hline $\begin{array}{l}\text { Company Total Assets in US } \\
\text { (\$ billions) }\end{array}$ & $\begin{array}{c}0.01 * * \\
(0.0274)\end{array}$ & $\begin{array}{l}0.02 * * * \\
(0.0001)\end{array}$ & $\begin{array}{c}0.01 * * \\
(0.0193)\end{array}$ & $\begin{array}{l}0.02 * * * \\
(0.0001)\end{array}$ \\
\hline $\begin{array}{l}\text { Total FDI in US from listing firm country } \\
\text { (\$ billions) }\end{array}$ & $\begin{array}{c}-0.0033 * * * \\
(0.0001) \\
\end{array}$ & $\begin{array}{c}-0.0032 * * * \\
(0.0001)\end{array}$ & $\begin{array}{c}-0.0053 * * * \\
(0.0001)\end{array}$ & $\begin{array}{c}-0.0053 * * * \\
(0.0001)\end{array}$ \\
\hline Company from EU excluding UK & & & $\begin{array}{l}2.04 * * * \\
(0.0006) \\
\end{array}$ & $\begin{array}{l}2.04 * * * \\
(0.0006) \\
\end{array}$ \\
\hline Company from UK or Commonwealth country & & & $\begin{array}{l}3.29 * * * \\
(0.0001) \\
\end{array}$ & $\begin{array}{l}3.30 * * * \\
(0.0001) \\
\end{array}$ \\
\hline Company from Asia & & & $\begin{array}{c}-9.91 \\
(0.9942)\end{array}$ & $\begin{array}{c}-10.21 \\
(0.9940)\end{array}$ \\
\hline Model Chi-Squared & 188.0 & 186.8 & 240.76 & 240.31 \\
\hline
\end{tabular}

$* * * 1 \%$ significance level; $* * 5 \%$ significance level; * 10\% significance level 
Table 3 continued

Panel B: Listing Directly Versus Listing with ADRs Types 1, 2 and 3

Dependent variable equals one if common stock issued, zero if ADR

\begin{tabular}{|c|c|c|c|c|}
\hline & Model 1 & Model 2 & Model 3 & Model 4 \\
\hline Intercept & $\begin{array}{r}1.89 * * * \\
(0.0001)\end{array}$ & $\begin{array}{r}1.87 * * * \\
(0.0001) \\
\end{array}$ & $\begin{array}{c}0.64 * * \\
(0.0469)\end{array}$ & $\begin{array}{c}0.63 * * \\
(0.0499) \\
\end{array}$ \\
\hline Company Sales/GNP & $\begin{array}{c}-171.2^{* * * *} \\
(0.0001)\end{array}$ & $\begin{array}{c}-162.0 * * * \\
(0.0001)\end{array}$ & $\begin{array}{c}-131.3 * * * \\
(0.0001)\end{array}$ & $\begin{array}{c}-125.8 * * * \\
(0.0001)\end{array}$ \\
\hline Company Total Assets /GNP & $\begin{array}{c}2.17 \\
(0.3982) \\
\end{array}$ & & $\begin{array}{c}1.11 \\
(0.6725)\end{array}$ & \\
\hline $\begin{array}{l}\text { Company Sales in US } \\
\text { (\$ billions) }\end{array}$ & $\begin{array}{l}0.24 * * * \\
(0.0001) \\
\end{array}$ & $\begin{array}{l}0.23 * * * \\
(0.0001) \\
\end{array}$ & $\begin{array}{l}0.19 * * * \\
(0.0001)\end{array}$ & $\begin{array}{l}0.18 * * * \\
(0.0001)\end{array}$ \\
\hline Proportion of sales in US & $\begin{array}{l}1.54 * * * \\
(0.0034)\end{array}$ & $\begin{array}{l}1.56 * * * \\
(0.0030)\end{array}$ & $\begin{array}{c}1.47 * * \\
(0.0202)\end{array}$ & $\begin{array}{c}1.48 * * \\
(0.0188)\end{array}$ \\
\hline $\begin{array}{l}\text { Company Total Assets in US } \\
\text { (\$ billions) }\end{array}$ & $\begin{array}{c}0.01 * * \\
(0.0293)\end{array}$ & $\begin{array}{l}0.02 * * * \\
(0.0001)\end{array}$ & $\begin{array}{c}0.01 * * \\
(0.0147)\end{array}$ & $\begin{array}{l}0.02 * * * \\
(0.0001)\end{array}$ \\
\hline $\begin{array}{l}\text { Total FDI in US from listing firm country (\$ } \\
\text { billions) }\end{array}$ & $\begin{array}{c}-0.0032 * * * \\
(0.0001) \\
\end{array}$ & $\begin{array}{c}-0.0032 * * * \\
(0.0001)\end{array}$ & $\begin{array}{c}-0.0052 * * * \\
(0.0001) \\
\end{array}$ & $\begin{array}{c}-0.0052 * * * \\
(0.0001)\end{array}$ \\
\hline Company from EU excluding UK & & & $\begin{array}{l}2.08 * * * \\
(0.0002) \\
\end{array}$ & $\begin{array}{l}2.09 * * * \\
(0.0002)\end{array}$ \\
\hline Company from UK or Commonwealth country & & & $\begin{array}{l}3.33 * * * * \\
(0.0001)\end{array}$ & $\begin{array}{l}3.34 * * * \\
(0.0001)\end{array}$ \\
\hline Company from Asia & & & $\begin{array}{c}-15.17 \\
(0.9862)\end{array}$ & $\begin{array}{c}-15.14 \\
(0.9863)\end{array}$ \\
\hline Model Chi-Squared & 195.70 & 195.21 & 259.36 & 259.21 \\
\hline
\end{tabular}

$* * * 1 \%$ significance level; ** 5\% significance level; * $10 \%$ significance level

Table 4

Logit results: Listing on the NYSE versus Other Exchanges (with p-values) Dependent variable equals one if listed on NYSE, zero if elsewhere

\begin{tabular}{|c|c|c|c|c|}
\hline & Model 1 & Model 2 & Model 3 & Model 4 \\
\hline Intercept & $\begin{array}{l}-0.67 * * * \\
(0.0040) \\
\end{array}$ & $\begin{array}{l}-0.59 * * \\
(0.0109) \\
\end{array}$ & $\begin{array}{l}-0.67 * * \\
(0.0127) \\
\end{array}$ & $\begin{array}{l}-0.53 * * \\
(0.0420) \\
\end{array}$ \\
\hline Company Sales/GNP & $\begin{array}{c}-6.67 \\
(0.6570) \\
\end{array}$ & $\begin{array}{c}17.73 \\
(0.1296) \\
\end{array}$ & $\begin{array}{c}-16.78 \\
(0.3025) \\
\end{array}$ & $\begin{array}{c}10.47 \\
(0.3556) \\
\end{array}$ \\
\hline Company Total Assets /GNP & $\begin{array}{c}18.70^{*} \\
(0.0790)\end{array}$ & & $\begin{array}{c}24.17 * \\
(0.0686)\end{array}$ & \\
\hline $\begin{array}{l}\text { Company Sales in US } \\
\text { (\$ billions) }\end{array}$ & $\begin{array}{c}0.01 \\
(0.9030)\end{array}$ & $\begin{array}{c}-0.04 \\
(0.6055)\end{array}$ & $\begin{array}{c}0.02 \\
(0.8561)\end{array}$ & $\begin{array}{c}-0.04 \\
(0.6617) \\
\end{array}$ \\
\hline Proportion of sales in US & $\begin{array}{c}-0.78^{*} \\
(0.0644)\end{array}$ & $\begin{array}{l}-0.92 * * \\
(0.0272)\end{array}$ & $\begin{array}{c}-0.74^{*} \\
(0.0832)\end{array}$ & $\begin{array}{l}-0.88 * * \\
(0.0374) \\
\end{array}$ \\
\hline $\begin{array}{l}\text { Company Total Assets in US } \\
\text { (\$ billions) }\end{array}$ & $\begin{array}{l}0.34 * * * \\
(0.0017) \\
\end{array}$ & $\begin{array}{l}0.41 * * * \\
(0.0002) \\
\end{array}$ & $\begin{array}{l}0.33 * * * \\
(0.0030)\end{array}$ & $\begin{array}{l}0.41 * * * \\
(0.0002) \\
\end{array}$ \\
\hline $\begin{array}{l}\text { Total FDI in US from listing firm country ( } \$ \\
\text { billions) }\end{array}$ & $\begin{array}{l}0.0004 * \\
(0.0960)\end{array}$ & $\begin{array}{l}0.0005^{*} \\
(0.0758) \\
\end{array}$ & $\begin{array}{c}0.0005 \\
(0.1087) \\
\end{array}$ & $\begin{array}{c}0.0006 * \\
(0.0705) \\
\end{array}$ \\
\hline Company from EU excluding UK & & & $\begin{array}{c}0.85^{*} \\
(0.0815) \\
\end{array}$ & $\begin{array}{c}0.70 \\
(0.1403) \\
\end{array}$ \\
\hline Company from UK or Commonwealth country & & & $\begin{array}{c}-0.16 \\
(0.6224) \\
\end{array}$ & $\begin{array}{c}-0.25 \\
(0.4345) \\
\end{array}$ \\
\hline Company from Asia & & & $\begin{array}{c}-0.77 \\
(0.5329) \\
\end{array}$ & $\begin{array}{c}0.23 \\
(0.8332) \\
\end{array}$ \\
\hline Model Chi-Squared & 90.74 & 86.34 & 96.57 & 90.98 \\
\hline
\end{tabular}

*** $1 \%$ significance level; ** 5\% significance level; * 10\% significance level

The arguments with regard to the decision of foreign firms to list directly or with ADRs should hold for the decisions regarding whether to list on the NYSE versus elsewhere. Our results are provided in Table 4. We find 
significant statistical support for the importance of proportion of sales in the U.S., the market focus hypothesis, and the level of assets in the U.S., the public relations hypothesis in all four models. We find weak support for the free rider effect; the total FDI in the U.S. from the firm's home country is significant at the $10 \%$ level in three of the four models, insignificant in one. We find that the level of sales in the U.S. does not have an impact on the likelihood that a firm lists on the NYSE (nor does the level of company sales relative the firm's home country GNP). This may be explained by the NASDAQ's recent importance for newer and more-technologically oriented firms, which will likely have lower home sales and greater overseas and U.S. sales.

\section{CONCLUSIONS}

Our results indicate that commitment signals are important in determining decisions regarding how and where firms list in the U.S. The cost associated with the listing decision - including the greater scrutiny of U.S. investors - signals the depth of the firm's commitment to the U.S. market to potential business partners and employees, providing a form of bonding that is directed within the U.S. Firms can credibly signal their greater commitment to the U.S. market by listing on more prestigious exchanges that bring greater investor scrutiny and, especially, by listing directly rather than using ADRs.

We find strong support for the hypotheses that firms with a greater level of sales and those with a greater proportion of their sales to the U.S. are more likely to list directly in the U.S. The evidence also supports the hypothesis that firms with greater assets in the U.S. are more likely, for public relations and political reasons, to list directly in the U.S. With the greater scrutiny for companies that list on the NYSE, we expect the hypotheses to hold for the decision to list on the NYSE versus elsewhere. With the exception of the sales level in the U.S., we find evidence for each of the relationships described above for the decisions of firms to list on the NYSE versus lower profile exchanges. We interpret the results as complementing the findings of Doidge (2004) and Doidge, Karolyi, and Stulz (2004) that listing in the U.S. provides protection for minority investors.

\section{AUTHOR INFORMATION}

Timothy Kruse, Ph.D. is an Assistant Professor of Finance, Williams College of Business, Xavier University, Cincinnati, $\mathrm{OH}$ 45207. His research interests are both U.S. and international mergers and acquisitions and corporate governance. E-mail: kruset@xavier.edu.

Michael Webb, Ph.D. is a Professor of Economics, Williams College of Business, Xavier University, Cincinnati, $\mathrm{OH}$ 45207. His research interests are in international business, governance, and international economics. E-mail: webbm@xavier.edu.

Shelly Webb, Ph.D. is a Professor of Finance, Williams College of Business, Xavier University, Cincinnati, OH 45207. Her research interests include managerial finance and business case writing. E-mail: webbs@xavier.edu.

\section{REFERENCES}

1. Biddle, G. and S. Saudagaran (1991), Foreign stock listings: benefits, costs, and the accounting policy dilemma, Accounting Horizons 5, 69-81.

2. Cheung, C. and J. Lee (1995), Disclosure environment and listing on foreign stock exchanges, Journal of Banking and Finance 19, 347-362.

3. Choi, F.D.S. and R.M. Levich (1990) The Capital Market Effects of International Accounting Diversity (Homewood, IL: Dow Jones-Irwin, 1990).

4. Doidge, C. (2004), U.S. cross-listings and the private benefits of control: evidence from dual-class firms, Journal of Financial Economics 72, 519-553.

5. Doidge, C., G.A. Karolyi and R.M. Stulz (2004), Why are foreign firms listed in the US worth more? Journal of Financial Economics 71, 205-238.

6. Doidge, C., G.A. Karolyi and R.M. Stulz (2009), Has New York Become Less Competitive in Global Markets? Evaluating Foreign Listing Choices over Time? Journal of Financial Economics 91, 253-277. 
7. Gagnon, L. and G.A. Karolyi, (2010), Do International Cross-listings still matter? Cornell University Johnson School Research Paper Series \#32-2010.

8. Lang, M.H., K.V Lins, and D.P. Miller, (2003), ADRs, Analysts, and Accuracy: Does Cross Listing in the United States Improve a Firm's Information Environment and Increase Market Value? Journal of Accounting Research 41, 317-345.

9. Mittoo, U. (1992), Managerial perceptions of the net benefits of cross-listing: Canadian evidence, Journal of International Financial Management and Accounting 4, 41-62.

10. Pagano, M. A. Röell, and J. Zechner (2002), The geography of equity listing: why do firms list abroad? The Journal of Finance 57, 2651-2694.

11. Salva, C. (2003), Foreign listings, corporate governance, and equity valuations, Journal of Economics and Business 55, 463-485.

12. Saudagaran, S. (1987), An empirical study of selected factors influencing the decision to list on foreign stock exchanges, Journal of International Business Studies 19, 101-128.

13. Saudagaran, S. and G. Biddle (1992), Financial disclosure levels and foreign stock exchange listing decisions, Journal of International Financial Management and Accounting 4, 106-148.

14. Saudagaran, S. and G. Biddle (1995), Cross-listing location: a study of MNC's and stock exchanges in eight countries, Journal of International Business Studies 26, 319-341.

15. Siegel, Jordan (2005), Can foreign firms bond themselves effectively by renting U.S. securities laws? Journal of Financial Economics 75, 319-359

16. Solnik (1988), International Investments, Addison Wesley.

17. Stulz, R.M. (1999), Globalization, corporate governance, and the cost of capital, Journal of Applied Corporate Finance 12, 8-25.

18. Sundaram, A.K. and D.E. Logue (1996), Valuation Effects of Foreign Company Listings on U.S. Exchanges, Journal of International Business Studies 27, 67-88. 


\section{APPENDIX A}

Data Distribution by Country

\begin{tabular}{|c|c|c|c|}
\hline Country & Number of observations & Number of ADRs & Percentage ADRs \\
\hline Antigua & 2 & 0 & $0 \%$ \\
\hline Argentina & 14 & 13 & 93 \\
\hline Australia & 26 & 24 & 92 \\
\hline Austria & 1 & 1 & 100 \\
\hline Bahamas & 3 & 0 & 0 \\
\hline Belgium & 3 & 1 & 33 \\
\hline Belize & 1 & 0 & 0 \\
\hline Bermuda & 65 & 5 & 8 \\
\hline Brazil & 45 & 45 & 100 \\
\hline British Virgin Islands & 16 & 0 & 0 \\
\hline Canada & 321 & 0 & 0 \\
\hline Cayman Islands & 33 & 11 & 33 \\
\hline Chile & 22 & 21 & 95 \\
\hline China & 14 & 14 & 100 \\
\hline Colombia & 1 & 1 & 100 \\
\hline Denmark & 6 & 5 & 83 \\
\hline Dominican Republic & 1 & 1 & 100 \\
\hline Finland & 4 & 4 & 100 \\
\hline France & 43 & 43 & 100 \\
\hline Germany & 30 & 28 & 93 \\
\hline Greece & 5 & 5 & 100 \\
\hline Hong Kong & 12 & 10 & 83 \\
\hline Hungary & 1 & 1 & 100 \\
\hline India & 17 & 17 & 100 \\
\hline Indonesia & 2 & 2 & 100 \\
\hline Ireland & 13 & 13 & 100 \\
\hline Israel & 92 & 8 & 9 \\
\hline Italy & 12 & 12 & 100 \\
\hline Japan & 46 & 44 & 96 \\
\hline Liberia & 5 & 0 & 0 \\
\hline Luxembourg & 13 & 8 & 62 \\
\hline Marshall Islands & 6 & 0 & 0 \\
\hline Mexico & 43 & 40 & 93 \\
\hline Netherlands & 43 & 28 & 65 \\
\hline Netherlands Antilles & 8 & 0 & 0 \\
\hline New Zealand & 1 & 1 & 100 \\
\hline Norway & 8 & 8 & 100 \\
\hline Panama & 4 & 0 & 0 \\
\hline Papua New Guinea & 1 & 1 & 100 \\
\hline Peru & 1 & 1 & 100 \\
\hline Philippines & 4 & 3 & 75 \\
\hline Portugal & 2 & 2 & 100 \\
\hline Russia & 14 & 14 & 100 \\
\hline Singapore & 11 & 6 & 55 \\
\hline South Africa & 14 & 13 & 93 \\
\hline South Korea & 13 & 12 & 92 \\
\hline Spain & 9 & 8 & 89 \\
\hline Sweden & 14 & 12 & 86 \\
\hline Switzerland & 21 & 19 & 90 \\
\hline Taiwan & 11 & 11 & 100 \\
\hline Turkey & 1 & 1 & 100 \\
\hline United Kingdom & 107 & 103 & 96 \\
\hline Venezuela & 2 & 2 & 100 \\
\hline
\end{tabular}




\section{NOTES}

